\title{
VOJAŠKO IZOBRAŽEVANJE V SLOVENSKI VOJSKI - IZZIVI PRIHODNOSTI
}

\section{MILITARY EDUCATION IN THE SLOVENIAN ARMED FORCES - FUTURE CHALLENGES}

Povzetek V članku sta prikazana na arhivskih virih in literaturi z analizo SWOT temelječa vojaško izobraževanje v Slovenski vojski in možnost njegovega nadaljnjega razvoja. Opisano je povezovanje vojaškega izobraževalnega in znanstvenoraziskovalnega sistema v Slovenski vojski s sistemom izobraževanja in znanstvenoraziskovalnega dela v Republiki Sloveniji ter v mednarodnem okolju tako, da je prikazan razvoj vojaškega izobraževanja v oboroženih silah Republike Slovenije, ki se je z njenim nastankom leta 1991 na novo oblikovalo, in to od osnovnega usposabljanja vojakov nabornikov do najvišjih oblik vojaškega izobraževanja in znanstvenoraziskovalnega dela na področju vojaških ved. V nadaljevanju so predstavljene pomanjkljivosti sedanjega vojaškega izobraževanja in njegov mogoč razvoj, ki bi potekal, tako kot v drugih zavezniških državah, v smeri vključevanja v bolonjski izobraževalni in znanstvenoraziskovalni sistem.

Ključne Republika Slovenija, Slovenska vojska, vojaško izobraževanje, bolonjski besede izobraževalni sistem, analiza SWOT.

Abstract The article depicts the military education model of the Slovenian Armed Forces and the possibility of its further development, which are both based on archive resources and SWOT analysis. It describes the integration of the military education and scientific and research system in the Slovenian Armed Forces with the education system and scientific research system in the Republic of Slovenia and internationally. It first describes the development of military education in the armed forces of the Republic of Slovenia, which was formed anew after Slovenia gained independence in 1991. It ranges from the basic conscript training to the most advanced forms of military education and scientific and research efforts in the field of military science. The article continues by presenting the shortfalls of the current military education system and possible ways of its development, which can be directed in a similar way 
as in other allied nations, namely by incorporating it into the Bologna education system and scientific research system.

Key words Republic of Slovenia, Slovenian Armed Forces, military education, Bologna education system, SWOT analysis.

\section{Uvod "Znanost lahko koristi pri vodenju oborožitve.॥}

Misel je razvil podpolkovnik baron Jurij Vega v prošnji cesarju Jožefu II. za dovoljenje, da bi smel kot učitelj matematike na bombardski šoli prostovoljno sodelovati v vojni z osmanskimi Turki, ki se je začela leta 1788. V bitki pri Beogradu je Jurij Vega ukazal močnejše nabijanje možnarjev, ustrezno je popravil nagib cevi in izboljšal tesnjenje med cevjo ter izstrelkom, in sicer tako, da je uporabil koščke lesa. Možnarji so po opravljenih spremembah učinkoviteje zadevali cilje. Pruski minister Hertzberg je ugotovil: »da je Vegovo odkritje smrtonosen strel za Turke« (Pisanski, 2006).

V preteklosti so številni avtorji, ki so bili tako ali drugače del procesa vojaškega izobraževanja Slovenske vojske, vsak iz svojega, pa vendar skupnega, imenovalca predlagali izpopolnitev sedanjega sistema vojaškega izobraževanja v Slovenski vojski: Liliana Brožič v članku Izobraževanje v oboroženih silah, Igor Kotnik v članku Raznolikost izobraževanja vojaških častnikov, Mojca Pešec in Uroš Krek v članku Can the process of professional military education create military strategists, Dušan Toš v članku Slovensko vojaško šolstvo, zamujena priložnost in izzivi v prihodnosti ter Vinko Vegič in Stojan Zabukovec v članku Izobraževanje častnikov: od razprav o organiziranosti $k$ razmisleku o vsebinah. Pri tem ne smemo prezreti tudi strokovnjakov zunaj Slovenske vojske, ki so tej problematiki posvetili veliko pozornosti. Izmed teh bi rad izpostavil predvsem članek Antona Žabkarja in Uroša Sveteta o šolanju vojaških profesionalcev.

Kot je zapisano v aktualni Doktrini vojaškega izobraževanja in usposabljanja Slovenske vojske: »Vojska potrebuje izobražene in dobro izurjene, disciplinirane, osebnostno zrele ter visoko etične pripadnike. Potrebuje vojake, ki jim znanje in veščine omogočajo kritično presojati in se aktivno odzivati na spremembe $v$ kompleksnih razmerah. Potrebuje voditelje z moralno integriteto, ki imajo znanje in sposobnosti za delovanje na različnih ravneh doma in v mednarodnih vojaških strukturah ter so sposobni delovati v različnih okoljih in sodelovati z nevojaškimi akterji. Potrebuje vojake, ki so sposobni vzpostaviti ustrezno razmerje med zahtevami vojaške hierarhije in discipline po eni ter potrebo po ustvarjalnosti, iniciativnosti in svobodi kritične misli ter izmenjavi strokovnih mnenj po drugi strani. Potrebuje vojake, ki sledijo načelom in pravilom vojaške doktrine naše vojske in zavezništva, vojake z moralnimi in etičnimi značilnostmi, ki jim narekujejo zavzeto in predano opravljanje poklica, so lojalni, domoljubni in tovariški. Njihovo vodilo pri opravljanju nalog je med drugim tudi kodeks vojaške etike.« (Doktrina VIU, 2013) Iz tega izhaja, da je postal prehod vojaškega izobraževanja, ki se v Slovenski vojski 
zdaj izvaja kot interno, na raven vsebinskega in organizacijskega povezovanja in integracije $\mathrm{z}$ višješolskim ter visokošolskim bolonjskim izobraževalnim sistemom na nacionalni in mednarodni (vojaški) ravni nuja nadaljnjega razvoja in posledično preživetja organizacije.

V članku razčlenjujemo z analizo SWOT (Vaupotič, 2012) vojaško izobraževanje v Slovenski vojski in možnost njegovega nadaljnjega razvoja oziroma povezovanje vojaškega izobraževalnega in znanstvenoraziskovalnega sistema v Slovenski vojski s sistemom izobraževanja in znanstvenoraziskovalnega dela v Republiki Sloveniji ter v mednarodnem okolju.

\section{PREDNOSTI SISTEMA VOJAŠKEGA IZOBRAŽEVANJA V SLOVENSKI VOJSKI}

\subsection{SV ima oblikovan interni sistem vojaškega izobraževanja in usposabljanja, ki deluje večinoma nespremenjen od leta 1992}

V nasprotju z operativnim delom Teritorialne obrambe (TO), ki so ga po obrambni vojni »zgolj« preoblikovali iz vojnega v mirnodobno stanje, je bilo treba postaviti sistem izobraževanja in usposabljanja starešin TO popolnoma na novo. Že 16. decembra 1991 so začeli delati častniki in podčastniki, ki so pripravili vse nujno za začetek izobraževanja in usposabljanja slušateljev na Šoli za podčastnike (ŠPČ). Prva generacija 58 slušateljev je začela šolanje 6. januarja 1992 in ga končala 16. maja istega leta. Šola je bila temeljna za poznejše oblikovanje Izobraževalnega centra Ministrstva za obrambo Republike Slovenije (IC MORS) kot organizacijske enote v sestavi Ministrstva za obrambo Republike Slovenije oziroma Centra vojaških šol (CVŠ), ki je leta 1999 postal sestavni del Slovenske vojske in v katerem so, zraven ŠPČ, kot prve delovale Šola za častnike (ŠČ), Šola za častnike (rezervnih) vojnih enot ( (̌́ ̌ VE) in Poveljniško-štabna šola (PŠŠ), z njimi pa tudi temelj organiziranega izobraževanja in usposabljanja starešin TO (Kladnik, 2007).

Z namenom povezave vojaškega izobraževanja in usposabljanja z znanstvenoraziskovalnim delom na področju vojaške znanosti in doktrin ter posledično pridobitvijo možnosti neposrednega uvajanja novega vojaškega znanja skozi šolski sistem v prakso sta se leta 2004 s Poveljstvom za doktrino, razvoj, izobraževanje in usposabljanje (PDRIU) povezala Center vojaških šol in Delovna skupina za doktrino in razvoj Generalštaba Slovenske vojske. Tako se je vzpostavil sistem vojaškega izobraževanja in usposabljanja, ki je obsegal temeljno, osnovno in dopolnilno vojaško izobraževanje in usposabljanje. Zagotavljal je sistematično in načrtno pripravo za začetne dolžnosti v vojaškem poklicu, nenehno izboljševanje vojaškostrokovne usposobljenosti, usposabljanje za tipične dolžnosti $\mathrm{v}$ posameznem vojaškem poklicu ter usposabljanje vojaških enot za učinkovito izvajanje nalog. Sistem je omogočal redne oblike izobraževanja in usposabljanja iz dela ter izobraževanje in usposabljanje ob delu ter na daljavo. Po obsegu, organizaciji in vsebini izobraževanja in usposabljanja je bil prilagojen načrtovani strukturi in nalogam vojske s težiščem 
na praktičnem usposabljanju posameznika in osnovnih taktičnih enot. Zagotavljal je takšno raven vojaške izobrazbe in usposobljenosti, ki je omogočala gibljivost vojaškega kadra znotraj celotnega obrambnega sistema ter prehodnost iz civilnih poklicev v vojaške in obratno. Posebna pozornost pa je bila pri tem usmerjena $\mathrm{v}$ razvoj osnovnih vojaških veščin in ved. Tako je postal PDRIU nosilec vojaškega izobraževanja in usposabljanja ter znanstvenoraziskovalnega dela in tehnološkega razvoja vojske. Pri izvajanju vojaškega izobraževanja in usposabljanja je sodeloval z domačimi in tujimi izobraževalnimi ustanovami ter enotami Slovenske vojske. S sodelovanjem civilnih izobraževalnih ustanov so se izvajale predvsem najvišje oblike izobraževanja, kot je podiplomski študij. Z vgradnjo vojaških modulov v programe višjih in visokih šol ter fakultet pa se je uvajalo tudi izobraževanje za pridobitev osnovne izobrazbe, medtem ko se je dopolnilno vojaško izobraževanje in usposabljanje izvajalo tudi v tujini (Kladnik, 2007).

Z reorganizacijo Slovenske vojske se je maja 2013 ustanovil Center vojaških šol (CVŠ), katerega poslanstvo so ustvarjanje in pridobivanje vojaškega znanja ter razvoj vojaških znanstvenih disciplin, vojaških ved in z njimi povezanih ved, na katerih temeljijo njihovi študijski programi $\mathrm{z}$ namenom izvajanja poslanstva Slovenske vojske. Kakovost delovanja CVŠ zagotavljajo vrednote, iz katerih izhajajo: odličnost študijskih programov in programov usposabljanja, harmoničnost kolektiva, strokovna rast ter dobro počutje slušateljev, odprt odnos med predavatelji, tutorji in slušatelji ter učinkovito vključevanje $\mathrm{v}$ mednarodno izobraževalno in znanstveno dejavnost ter se zato povezovati s sorodnimi ustanovami doma in v svetu. Naloge CVŠ, ki izhajajo iz poslanstva CVŠ, so: izvedba vojaških izobraževalnih programov in programov vojaškega usposabljanja, doseganje kakovostnih meril, $h$ katerim zavezuje zakonodaja, ter meril, ki jih predpisujeta in priporočata Nato in EU, raziskovanje in razvoj na področju vojaških ved ter z njimi povezanimi vedami, skrb za vojaško kulturno dediščino, priprava vojaškostrokovne literature, učbenikov in študijskega gradiva, razvoj učnih pripomočkov in učne infrastrukture, programiranje in razvoj programov, načrtovanje izvedbe izobraževanja in usposabljanja, evalvacija izobraževanja in usposabljanja, elektronsko izobraževanje, sodelovanje z izobraževalnimi in raziskovalnimi ustanovami, sodelovanje in izmenjava znanja z drugimi ustanovami ter knjižnično-informacijska in založniška dejavnost (SOP CVŠ, 2015).

\subsection{SV ima habilitirane in druge strokovnjake, ki bi jih ob ustreznem kadrovskem izboru in poklicni poti usmerili v razvoj vojaških ved}

Kot je zapisano v Doktrini VIU (2013), se v SV kot izvajalci vojaškega izobraževanja in usposabljanja vključujejo različni strokovnjaki. Za kader, ki opravlja pedagoško delo, morajo biti izbrani posamezniki, ki so prepoznani kot najboljši poznavalci vojaške in obrambne stroke, imeti pa morajo tudi možnost nenehnega dopolnjevanja znanja. Zato je treba ohraniti kakovostni standard pedagoško-andragoškega znanja izvajalcev izobraževanja in vztrajati z uveljavitvijo zahteve po certifikatu o pedagoški usposobljenosti, ki ga mora imeti vsak pripadnik, ki predava ali uri vojake v ustanovah VIU. V SV sta izobraževanje in usposabljanje zaupana izvajalcem, ki 
so na formacijskih mestih učiteljev, in tistim, ki v proces vstopajo, kadar je treba (častniki in podčastniki, vojaški uslužbenci ter zunanji sodelavci), morajo pa izpolnjevati pogoje za opravljanje teh nalog.

\subsection{SV ima opremo in infrastrukturo za izvedbo izobraževalnega in znanstvenoraziskovalnega dela}

Prilagajanje pogojev usposabljanja realnim razmeram uporabe in delovanja enot ter poveljstev je bilo izhodišče za vlaganje v objekte, opremo in sredstva za usposabljanje. Tako so bili v sistemu izobraževanja in usposabljanja zagotovljeni simulatorji, naprave, pripomočki in simulacije za virtualno usposabljanje posameznikov, posadk in enot, kot so simulatorji in trenažerji za oborožitvene sisteme, bližinski boj, streljanje itn. Prav tako pa je s simulatorji in simulacijskimi programi podprto usposabljanje poveljstev in enot od voda navzgor, kot so bataljonski, brigadni in divizijski simulacijski program, z možnostjo povezave v kombinirane in združene mednarodne vaje. $Z$ oblikovanjem in opremljanjem Centra za bojno usposabljanje v Postojni ter nabavo laserskih tehničnih sistemov in streliva za urjenje so se vzpostavili tudi nujne zmogljivosti in pogoji za usposabljanje enot do ravni bataljonske bojne skupine. Ustrezne terenske razmere za izvajanje izobraževanja in usposabljanja pa se vzpostavljajo tudi s posodabljanjem strelišč in vadišč Mlake in Apače. Ustrezna infrastruktura za taktično urjenje, strelsko kondiciranje in šport pa se zagotavljajo tudi znotraj posameznih vojašnic Slovenske vojske. Sodobne razmere za namestitev in delovanje vojaškega izobraževalnega sistema pa so bile zagotovljene $\mathrm{z}$ obnovo in revitalizacijo kompleksa Vojašnice generala Maistra v Mariboru oziroma objekta Kadetnica (Kadetnica, 2011).

\subsection{SV ima Knjižnično-informacijski in založniški center}

Knjižnično-informacijsko in založniški center MO RS je specialna knjižnica $\mathrm{v}$ sistemu javne uprave in osrednja knjižnica MO RS. Organizacijsko je umeščen k CVŠ, s svojim delovanjem pa zagotavlja knjižnično, dokumentacijsko, informacijsko in založniško podporo vsem pripadnikom SV in uslužbencem MO RS ter hiter in neoviran dostop do virov, ki jih potrebujejo pri delu in izobraževanju. Kot osrednja knjižnica ministrstva uresničuje svoje poslanstvo z nalogami vodenja in knjižnične podpore vsem OE v sistemu MO ter Slovenske vojske. Za vse OE izvaja postopke nakupa, strokovne obdelave in distribucije knjižnično-informacijskih virov. Poleg tega izvaja zanje matično službo. Matična služba zagotavlja in daje strokovno podporo knjižnično-informacijskim točkam (KIT) v vseh odsekih njihovega delovanja. Informacijska služba posreduje uporabnikom podatke iz slovenskega knjižnično-informacijskega sistema COBISS/OPAC in mednarodnih podatkovnih zbirk, zagotavlja prost dostop do strokovnih časopisov ter neknjižnega gradiva. Kot aktivni član sodeluje v Nacionalnem vzajemnem bibliografskem sitemu Cobiss, kar pomeni, da prevzema obveznosti in naloge, ki izhajajo iz tega. Tako sodeluje v procesih vzajemne katalogizacije, knjižnično gradivo iz zaloge Knjižničnoinformacijskega centra MO RS pa je javno dostopno v elektronskem katalogu Cobiss, do katerega imajo prosti dostop uporabniki, ki jih to zanima. Prav tako spada 
med njegove naloge vodenje bibliografije strokovnih delavcev in raziskovalcev tako Ministrstva za obrambo RS kot pripadnikov Slovenske vojske. Do Digitalne knjižnice MO RS lahko dostopajo vsi zaposleni z MO, ne glede na svojo fizično lokacijo ali specifiko delovnega mesta, ker zagotavlja enake možnosti dostopa do informacij vsem pripadnikom Slovenske vojske. To je tudi zelo pomembno zaradi razpršenosti rednih in rezervnih enot Slovenske vojske in različnih kriznih žarišč, na katerih delujejo pripadniki. Digitalna knjižnica omogoča dostop do publikacij, ki jih izdaja založniška služba ministrstva, zaključnih nalog vojaških izobraževalnih programov in zaključnih nalog zaposlenih na ministrstvu, ki imajo sklenjeno pogodbo o izobraževanju v civilnih izobraževalnih ustanovah, zaključnih poročil CRP-MIR, raziskovalnih poročil TP-MIR in znanstvenih časopisov MO. Zaposlenim na MO RS omogoča tudi dostop do plačljivih virov IHS Jane's, Military Periscope, Stratfor, ProQuest in EBSCO (SOP CVŠ, 2015).

\subsection{SV ima znanstveno-strokovno publikacijo}

Slovenija ima samo eno znanstveno-strokovno publikacijo, ki je namenjena vojaškoobrambnim vsebinam. Izdaja jo Generalštab Slovenske vojske. Jeseni 1999 je izšla prva številka publikacije Bilten Slovenske vojske, ki jo je izdal Generalštab Slovenske vojske. Njen namen je bil, da pripadniki Slovenske vojske in Ministrstva za obrambo, ki so se izobraževali in usposabljali doma in v tujini, svoje izkušnje zapišejo ter jih tako delijo z drugimi. Leta 2011 se je Bilten preimenoval v Sodobne vojaške izzive ali angleško v Contemporary Military Challenges, kar odraža bistvo publikacije Slovenske vojske in to je vojaštvo (Military). Iz prvih pridevnika in samostalnika je razvidno, da gre za aktualno vojaško tematiko, in ne za zgodovinske vsebine. Teh imamo v Republiki Sloveniji precej, zato je aktualnost vsebin, ki jih izdaja Slovenska vojska, tista pomembna prepoznavna lastnost, ki jo sporoča novo ime. Slovenska vojska ima zagotovo največ priložnosti biti v stiku z aktualnimi dogodki in trendi na obrambno-varnostnem področju. Če dobro prakso združimo z aktualno teorijo in omogočimo nove ugotovitve, rešitve ali predloge, smo zagotovo na dobri poti v prihodnost. S pisanjem o aktualnih obrambnovojaških vsebinah delimo znanje in izkušnje z drugimi domačimi in tujimi avtorji ter bralci. Na prvem mestu po objavljanju člankov v Sodobnih vojaških izzivih so tako zaposleni v Slovenski vojski, na drugem različni slovenski avtorji, sledijo avtorji iz tujine. Publikacija je uvrščena v bibliografsko zbirko podatkov COBISS.SI in PAIS International ter je $\mathrm{v}$ postopku za vključitev v bazo Scopus (Brožič, 2014).

\subsection{SV ima v omejenem obsegu na razpolago ustrezne finance za izvedbo vojaškega izobraževanja}

»Padanje deleža obrambnih izdatkov v BDP se bo leta 2017 ustavilo pri 0,91 odstotka. Od leta 2018 do 2020 se bo delež obrambnih izdatkov v BDP postopno povečeval do 1,03 odstotka BDP. V povprečju se bodo obrambni izdatki od leta 2017 med letom povečali za okoli 35 milijonov evrov in bodo leta 2020 dosegli 478 milijonov evrov, kar je 104 milijone evrov več kot leta 2017. Stroški za investicije $v$ modernizacijo obrambnih zmogljivosti bodo v obdobju 2016-2018 še vedno 
neuravnoteženo in nezadostno rastli ter bodo leta 2018 dosegli 4 odstotke v strukturi obrambnih izdatkov oziroma petino ciljnega deleža (20 odstotkov). V letih 2019 in 2020 se bo ta delež povečal na 9 oziroma 15 odstotkov. Stroški za osebje bodo glede na leto 2016, ko predstavljajo v strukturi obrambnih izdatkov več kot 80 odstotkov, postopno padali in bodo leta 2020 predstavljali 67 odstotkov. Leta 2020 bo razmerje med stroški za osebje, operativnimi stroški in stroški investicij znašalo $67: 18: 15$, kar predstavlja premik v smeri ciljnega razmerja 50:30:20. Stroški za osebje bodo predstavljali največji strošek v strukturi obrambnih izdatkov«(SOPR, 2015).

Slika 1:

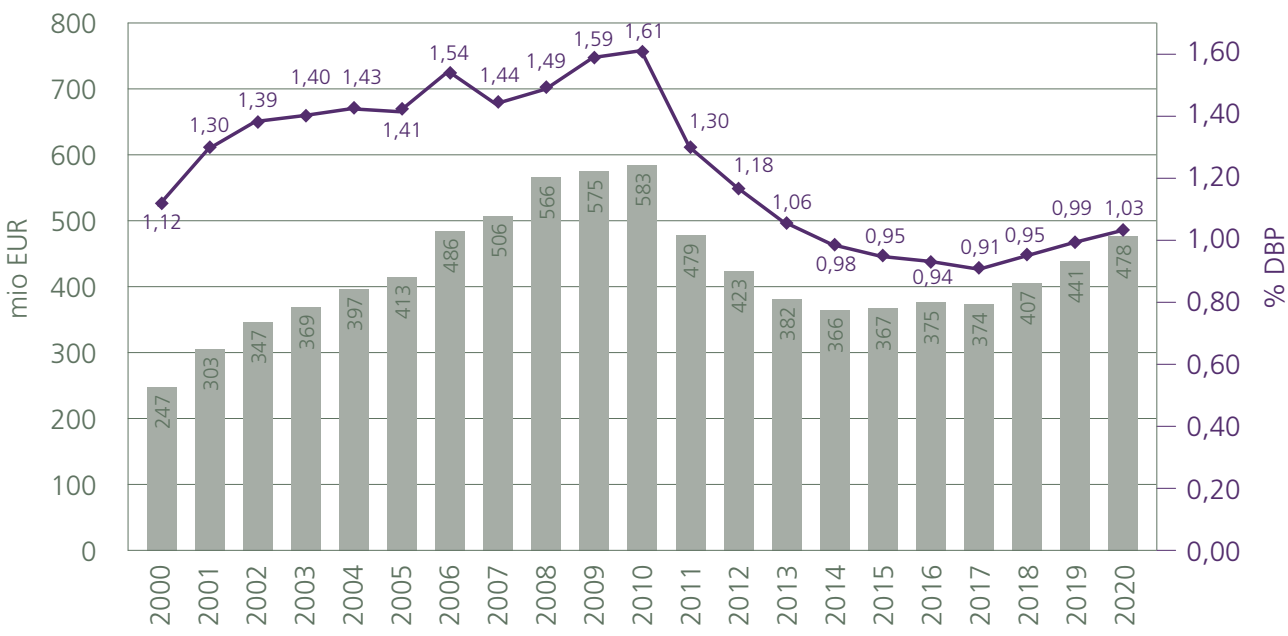

$\mathrm{Ol}($ mio EUR $) \rightarrow \mathrm{OI}(\% \mathrm{BDP})$

\subsection{SV ima dostop in možnost povezovanja ter izmenjave učiteljev in študentov ter vključevanja v znanstvenoraziskovalne projekte v Natu in EU}

Za zagotovitev in izboljšanje kakovosti vojaškega izobraževanja je bila v okviru Nata sprejeta odločitev, da se izvede uvedba mednarodnih standardov na področju vojaškega izobraževanja v okviru ustanov, ki za Natove potrebe izvajajo izobraževanje in usposabljanje (vključene so tudi partnerske države). Uvedba standardov obsega uvajanje treh pomembnih sestavin: izobraževalni cilji, izobraževalni standardi in proces zagotavljanja kakovosti. V direktivi, ki vsebuje tudi Koncept izobraževalnih standardov in Standarde ter napotila za zagotavljanje kakovosti na področju izobraževanja in usposabljanja, je razložen postopek za akreditacijo Nata in partnerskih izobraževalnih ustanov. Novi način akreditacije znotraj Nata akreditacija izobraževalnih ustanov (in ne posameznih programov) - se je začel 1. junija 2012. V procesu akreditacije bodo najprej sodelovale ustanove, ki se bodo za to prostovoljno prijavile in že večinoma zagotavljajo pogoje iz minimalnih meril 
za zagotavljanje kakovosti. Postopek bo potekal tako: ustanova najprej izpolni vprašalnik o zagotavljanju kakovosti in ga pošlje v Joint Task Force (JFT), v JFT skrbno proučijo vprašalnik in pripravijo ekipo za obisk v ustanovi, obisk se izvede skladno z Opomnikom za zagotavljanje kakovosti, v JFT pripravijo poročilo, v katerem predlagajo: takojšnjo akreditacijo ustanove, pogojno akreditacijo ( 9 mesecev za odpravo pomanjkljivosti), odloženo akreditacijo (18 mesecev do naslednje evalvacije), poročilo je dostopno ustanovi, ki se ocenjuje, in ACT, akreditacija načeloma velja približno 6 let. Tak proces bodo morale imeti vse ustanove, ki bodo v prihodnosti želele svoje usluge predstavljati na »Natovem trgu IU«, saj bodo lahko vstopile v Natov Training Management System le ustanove, ki zagotavljajo ustrezne kakovost in standarde usposabljanja. Tako želijo v JFT zagotoviti ustrezno visoke standarde na področju IU in ustrezno usposobljeno osebje tako v Natovi poveljniški strukturi kot tudi v operacijah (Natov Education and Training Directive, 2013).

Veliko možnosti za sodelovanje na mednarodnem področju izhaja tudi iz našega članstva $\mathrm{v}$ formalnih in neformalnih združenjih vojaških izobraževalnih ustanov. Tako je na primer CEFME (Konferenca poveljnikov vojaških izobraževalnih ustanov srednje Evrope), priložnost za izmenjevanje izkušenj in predlogov na področju razvoja in povezovanja vojaškega izobraževanja. Sodelovanje med članicami CEFME se izraža tudi $\mathrm{z}$ izmenjavo sodelovanja $\mathrm{v}$ pedagoških in znanstvenoraziskovalnih projektih, tako pri že uveljavljenih kot pri oblikovanju novih. Pri tem je pomembno predvsem sodelovanje v projektu Perspektiva EU 2020 in pri pisanju ter izmenjavi znanstvenih člankov na področju vojaških ved $\mathrm{v}$ skupni reviji CEFME ter $\mathrm{v}$ nacionalnih revijah. CEFME pa organizira tudi vsakoletno konferenco študentov, ki na njej aktivno sodelujejo s svojimi strokovnimi prispevki.

\section{SLABOSTI SISTEMA VOJAŠKEGA IZOBRAŽEVANJA V SLOVENSKI VOJSKI}

\subsection{SV ni nosilec razvoja vojaških ved in vojaškega poklica}

Po določilih Doktrine VIU (2013) so: »Raziskave in razvoj namenjeni napredku vojaškega izobraževanja in usposabljanja. Obsegajo razvoj vojaške stroke, vojaških ved in vojaške strokovne literature, programskooblikovanje VIU, uvajanje standardov, novega znanja in novih oblik izobraževanja v programe VIU, prenašanje izkušenj v proces VIU in načrten razvoj kadra za VIU. Razvoj vojaške stroke in vojaških ved se uresničuje tudi z znanstvenoraziskovalno dejavnostjo. Znanstvenoraziskovalna dejavnost v SV se izvaja skladno z zakonskimi določili, ki urejajo področje v Republiki Sloveniji, in merili za vrednotenje uspeřnosti znanstvenoraziskovalnega dela. Nosilec raziskovalnega področja v SV je institucija, ki je zadolžena za izvajanje temeljne in aplikativne raziskovalne dejavnosti v SV. Med institucijo, ki je nosilka raziskav $v$ SV, je vzpostavljena povezava s centri za učenje iz izkušenj zavezniških držav in Natovim centrom (JALLC) in ostalimi institucijami doma in v tujini, ki se ukvarjajo z znanstvenoraziskovalno dejavnostjo pomembno za delovanje obrambnega sistema RS. Vzpostavljena je informacijska podpora za oblikovanje 
baze znanja, ki je dostopna vsem uporabnikom znotraj SV in interno izbranim uporabnikom.« Z reorganizacijo PDRIU se je leta 2013 preoblikoval in razpustil njegov temeljni del, Center za doktrino in razvoj, ki je podobno kot primerljive ustanove in centri povezoval pedagoško ter znanstvenoraziskovalno delo, tudi sistemsko znanstvenoraziskovalno delo in razvoj na področju vojaških ved in prenos spoznanj s pedagoškim procesom v prakso. Če so procesi na področju pedagoškega področja in izvajanja internega vojaškega izobraževanja in usposabljanja bolj ali manj ustrezno prešli pod CVŠ, pa so procesi s področja znanstvenoraziskovalnega dela kar nekako umanjkali ali pa prešli pod GŠSV.

\subsection{SV nima oblikovane osrednje pedagoške in znanstvenoraziskovalne ustanove}

Poslanstvo CVŠ je, kot smo že zapisali, izvajanje izobraževanja, praktičnega izobraževanja in usposabljanja, urjenja ter poučevanja, pridobivanja vojaškega znanja ter razvoj vojaških znanstvenih disciplin, vojaških ved in z njimi povezanih ved, na katerih temeljijo njihovi študijski programi z namenom izvajanja poslanstva SV. Pri izvajanju aktivnosti se povezuje z javnim izobraževalnim sistemom kot tudi s primerljivimi sistemi znotraj zavezništva, predvsem pa s strukturami zavezniškega poveljstva za transformacijo (SOP CVŠ, 2015). V resnici pa je CVŠ tipično vojaško poveljstvo taktične ravni, ki nima vzpostavljenih temeljnih pedagoško-andragoških in znanstvenoraziskovalnih elementov, na katerih delujejo tradicionalne in sodobne pedagoške in znanstvenoraziskovalne ustanove tako civilnega kot tudi mednarodnega vojaškega izobraževalnega in znanstvenoraziskovalnega področja. $\mathrm{Na}$ primer poklicne poti za učitelje vojaških ved in njihova habilitacija, šolsko študijsko leto, izmenjava učiteljev in študentov v sistemu Erasmus itn.

\subsection{SV nima oblikovanega izobraževalnega in znanstvenoraziskovalnega sistema ter izoblikovanih in razvitih znanstvenih disciplin vojaških ved $z$ ustreznimi nosilci, ki bi se vključevali v (civilno) javno in mednarodno vojaško pedagoško in znanstvenoraziskovalno okolje}

V CVŠ deluje kot organizacijska enota Katedra vojaških ved, katere poslanstvo je izvajanje vojaškega izobraževanja in usposabljanja ter znanstvenoraziskovalnega dela na področju vojaških ved. Katedra vojaških ved tako združuje posamezne učitelje, ki so nosilci predmetnih področij in predavatelji posameznih predmetov ter izhajajo iz predmetnih področij na vseh ravneh vojaškega izobraževanja (vojak, podčastnik, častnik, vojaški uslužbenec). Z njimi sodelujejo pri izvedbi in razvoju procesa VIU posamezniki iz drugih enot vojske. Deluje predvsem na pedagoškem področju prenašanja znanja $\mathrm{v}$ internem sistemu vojaškega izobraževanja. $\mathrm{V}$ tem procesu nimajo omogočene pridobitve ustrezne licence, pedagoške habilitacije in usposobitve glede na raven poučevanja. Tako tudi za posamezno predmetno področje niso oblikovani strokovni aktivi, katerih naloga je oblikovati programe izobraževanja tako, da bi jih bilo mogoče skupaj z drugimi predmeti ustrezno akreditirati. Prav tako se z znanstvenoraziskovalnim delom nesistemsko ukvarjajo le posamezniki (SOP CVŠ, 2015). 


\subsection{SV nima javno akreditiranih programov izobraževanja}

Izobraževanje in usposabljanje vojakov, podčastnikov, častnikov in vojaških uslužbencev kot posameznikov poteka na treh različnih stopnjah:

- Temeljna - I. stopnja: obsega temeljno vojaškostrokovno usposabljanje (TVSU) za opravljanje vojaške službe (prostovoljno služenje vojaškega roka in usposabljanje za poklicno delo v stalni sestavi) in temeljno usposabljanje kandidatov za častnike SV. Izvaja se v treh programih, in sicer centralizirano, pod vodstvom in nadzorom Veščinskega centra v Vipavi, ter traja 3,5 meseca. Kandidati za častnike in kandidati za vojaške uslužbence opravijo zadnji mesec TVSU po posebnem programu.

- Osnovna - II. stopnja: zagotavlja znanje in veščine za opravljanje začetnih dolžnosti in obsega osnovno vojaškostrokovno usposabljanje (OVSU) vojakov, osnovno vojaškostrokovno izobraževanje in usposabljanje (OVIU) kandidatov za podčastnike, podčastnikov in častnikov ter osnovno usposabljanje za delo v vojski (OUZD) za nižje in višje vojaške uslužbence.

- Nadaljevalna - III. stopnja: obsega tiste oblike izobraževanja in usposabljanja za vojake, podčastnike in častnike, ki zagotavljajo pridobivanje višje stopnje vojaškostrokovne izobrazbe oziroma znanja in sposobnosti za opravljanje novih oziroma zahtevnejših dolžnosti v SV. Nadaljevalno vojaško usposabljanje za vojake - program za desetnike - obsega pridobivanje veščin, znanja in spretnosti za vsakodnevno opravljanje nalog ter vodenje in poveljevanje skupini, posadki in posamezniku. Nadaljevalna VIU za podčastnike potekajo na treh ravneh (program za štabne in enotovne podčastnike ter podčastnike specialiste, program višjega tečaja za podčastnike, program visokega tečaja za podčastnike) in se izvajajo doma ali v tujini. Nadaljevalna VIU za častnike obsegajo programe štabnega, višjega štabnega ter generalštabnega izobraževanja in usposabljanja za častnike SV. Izvajajo se na Poveljniško-štabni šoli SV, posamezniki pa se udeležujejo primerljivih oblik tudi v tujini (Doktrina, 2013; Predlog, 2014).

Vojaško izobraževanje $\mathrm{v}$ praksi ni usklajeno in opredeljeno kot strokovno izobraževanje, višje strokovno, visokošolsko izobraževanje in podiplomski študij, kot to predvidevajo predpisi javnega izobraževalnega bolonjskega sistema. V obdobju 2012/2013 je bilo prekinjeno sodelovanje oziroma izobraževanje z javnimi izobraževalnimi ustanovami, in sicer za podčastnike na višji stopnji, povezano z višjim štabnim tečajem za podčastnike ter za častnike na 2 . bolonjski stopnji, povezano z višjim štabnim šolanjem. Prav tako niso določene poklicne poti pedagoških in znanstvenoraziskovalnih delavcev. Programi vojaškega izobraževanja so se v posameznih primerih posodobili, vendar še niso javno akreditirani. 


\section{PRILOŽNOSTI ZA RAZVOJ SISTEMA VOJAŠKEGA IZOBRAŽEVANJA V SLOVENSKI VOJSKI}

3.1 SV postane skupaj s partnerskimi izobraževalnimi in znanstvenoraziskovalnimi ustanovami nosilec razvoja vojaških ved in vojaškega poklica

Vojaška znanost je sistem znanja, ved o vseh vrstah dejavnosti oboroženih sil v miru, krizah in vojnah ter o okoliščinah, v katerih se oborožene sile razvijajo in delujejo. Razvoj vojaških ved je temelj razvoja vojske. Zato mora vojska razviti svoj znanstvenoraziskovalni in izobraževalni sistem, ki je hkrati del »civilnega« javnega ter mednarodnega vojaškega znanstvenoraziskovalnega in izobraževalnega sistema (Žabkar, 2003). V vsebinskem in organizacijskem smislu to pomeni, da mora biti CVŠ organiziran in akreditiran kot izobraževalna in znanstvenoraziskovalna organizacija, saj bo lahko le tako enakovreden partner na slovenskem in mednarodnem znanstvenoraziskovalnem ter izobraževalnem področju.

Vojaške vede se delijo na:

- ortodoksne vojaške vede:

- strategija,

- operatika,

- taktika,

- logistika,

- vojaška geografija,

- vojaška zgodovina,

- voditeljstvo in menedžment,

- delovanje rodov oboroženih sil;

- vojaškotehnične vede - oborožitveni sistemi;

- vojaškodružboslovne vede - mednarodno vojno pravo, vojaška sociologija, vojaška psihologija, vojaška andragogika;

- vojaškomedicinske vede;

- vojaško jezikoslovje.

\subsection{SV skupaj s partnerskimi izobraževalnimi in znanstvenoraziskovalnimi} ustanovami s svojimi kadri (SV) vzpostavi osrednjo pedagoško in znanstvenoraziskovalno ustanovo v obliki inštituta vojaških ved

Inštitut vojaških ved izvaja vojaško izobraževanje in znanstvenoraziskovalno delo na področju vojaških ved $v$ sodelovanju z domačimi in tujimi partnerji, in sicer $\mathrm{z}$ vojaškim raziskovanjem, ustvarjanjem in pridobivanjem vojaškega znanja ter razvojem vojaških znanstvenih disciplin, vojaških ved in z njimi povezanih ved, na katerih temeljijo študijski programi inštituta. Izobraževanje je temeljno poslanstvo Slovenske vojske, zato tudi neovirano poteka. Inštitut skrbi za učinkovito vključevanje $\mathrm{v}$ javno in mednarodno vojaško izobraževalno ter znanstvenoraziskovalno dejavnost in se zato povezuje s sorodnimi ustanovami doma in v svetu. 
Učitelji in inštruktorji v zvezi s tem opravljajo naloge:

- predavanja na internih in akreditiranih programih,

- oblikovanje programov - prenova internih in priprava akreditiranih programov na vseh ravneh in smereh,

- oblikovanje elektronskih programov,

- priprava na izvajanje programov v angleškem jeziku,

- znanstvenoraziskovalno delo in priprava na habilitacije,

- priprava in izdaja učnih gradiv,

- strokovno povezovanje doma in v tujini.

Izbor učiteljev in inštruktorjev ter drugih sodelavcev v procesu VIU mora temeljiti na teh merilih:

- vojaškostrokovno znanje in pripravljenost za nenehno izpopolnjevanje predvsem izvajalcev izobraževanja in usposabljanja v ustanovah VIU ter učnih enotah, ki izvajajo temeljno in osnovno vojaško izobraževanje in usposabljanje,

- osebnostne lastnosti, ki so primerne za delo z mladimi in drugimi udeleženci,

- uspešno opravljeno pedagoško-andragoško usposabljanje za izvajalca vojaškega izobraževanja in usposabljanja,

- poznavanje koncepta izobraževanja in usposabljanja v Slovenski vojski,

- sprejemanje vrednostnega sistema in pravil, ki veljajo na področju izobraževanja in usposabljanja v Slovenski vojski.

V IVV se zato oblikujejo oddelki/inštituti, v katerih delujejo poklicni in nepoklicni učitelji, zaposleni $\mathrm{v}$ zavodu, učitelji iz enot SV in MO, učitelji iz civilnih izobraževalnih ustanov in učitelji iz tujih vojaških izobraževalnih ustanov.

\subsection{SV oblikuje skupaj s partnerskimi izobraževalnimi in} znanstvenoraziskovalnimi ustanovami izobraževalni in znanstvenoraziskovalni sistem ter izoblikuje in razvija znanstvene discipline vojaških ved z ustreznimi nosilci, ki so vključeni v (civilno) javno in mednarodno vojaško pedagoško ter znanstvenoraziskovalno okolje

»Ključni dejavniki, brez katerih se ne more oblikovati in organizirati nacionalni vojaški visokošolski sistem, je kakovostni predavateljski kader z doktorati, pridobljenimi na področju strategije in taktike. Ostali predavateljski kadri s področja vojaške tehnike, vojaške zgodovine, vojaške geografije in gostujoči predavatelji iz tujine so komplementarni in tudi pomembni, vendar se brez tistih, ki so doktorirali iz vojaških ved in se prebili od asistentov do profesorjev (na tej poti morajo objavljati številna znanstvena in strokovna dela), ne more ustvariti "gravitacijsko jedro« nacionalne vojaške znanosti niti organizirati podiplomsko študij. Sodobno vojaško visoko šolstvo (temeljno šolanje + specializacija + podiplomski študij) se ne pri nas ne $v$ tujini ne more oblikovati in delovati brez spoštovanja zakonskih aktov in norm, ki veljajo za nacionalne javne visoke šole (bolonjski proces), ter brez 
odpiranja javnosti. V tem sklopu je nujno poudariti, da SV nima podiplomskega študija s področja vojaških znanosti in da bi ga morala imeti, pri čemer bi ga morala povezati $v$ sistem nacionalnih visokih šol ter pri tem najtesneje sodelovati s civilnimi znanstveniki in univerzitetnimi predavatelji (oziroma visokošolskimi institucijami) doma in $v$ tujini. $V$ ta namen mora imeti lastne (ali v tujini najete) kakovostne predavateljske in raziskovalne kadre z javno pridobljenimi visokošolskimi in znanstvenimi nazivi, ki morajo prav tako tesno sodelovati s civilnimi univerzami in raziskovalnimi instituti. Nesporno dejstvo je, da se mora v času sedanje evropske in globalne strateške fluidnosti še veliko bolj kot nekoč upoštevati imperativ, da se, zlasti po sprejemu Slovenije v Evropsko unijo in Nato, vse institucije naše države (vključno z obrambnim sistemom in SV, ki je njegov pomemben sestavni del) ter slovenska družba kot celota pospešeno vključujejo v evropske tranzicijske procese in transatlantske integracije» (Žabkar, 2008).

Nosilci predmetov bi tako postali že habilitirani visokošolski učitelji, ki delajo v obrambnem sistemu, z njimi pa bi sodelovali posamezniki iz vojske z doktoratom znanosti, znanstvenim magisterijem in univerzitetno izobrazbo, in sicer kot visokošolski ali višješolski sodelavci (imenovani v naziv predavatelja, višjega predavatelja ali asistenta). Vsem bi bila omogočena pridobitev znanstvenega naziva. Visokošolski učitelji in sodelavci bi poleg pedagoškega procesa (poučevanje, oblikovanje programov, skript, učbenikov, e-učilnic idr.) opravljali tudi znanstvenoraziskovalno delo s svojega predmetnega področja. Katedra vojaških ved oziroma Inštitut vojaških ved bi skrbel za učinkovito vključevanje v mednarodno vojaško izobraževalno in znanstveno dejavnost ter se zato povezoval s sorodnimi ustanovami doma in v svetu. Zato se znotraj njega oblikujejo katedre/oddelki, v katere bodo vključeni poklicni učitelji, zaposleni v zavodu, učitelji iz enot SV in MO, učitelji iz civilnih izobraževalnih ustanov in učitelji iz tujih vojaških izobraževalnih ustanov. Poslanstvo katedre/inštituta bi torej bilo, da znotraj Slovenske vojske in ob sodelovanju z domačimi in tujimi partnerji z vojaškim raziskovanjem, ustvarjanjem in pridobivanjem vojaškega znanja ter razvojem vojaških znanstvenih disciplin, vojaških ved in z njimi povezanih ved, na katerih temeljijo njihovi študijski programi, zaradi izvajanja poslanstva Slovenske vojske izvaja vojaško izobraževanje in znanstvenoraziskovalno delo na področju vojaških ved. Pedagoška dejavnost bo poleg poučevanja obsegala usposabljanje za učitelje in mentorje, učiteljske konference, sodelovanje na simpozijih s področja izobraževanja, izmenjavo učiteljev, izbor učiteljskega kadra in odobravanje tem zaključnih nalog. Poleg pedagoške vloge učiteljev bo njihova skrb tudi znanstvenoraziskovalno delo v okviru predmeta, ki ga bodo poučevali. Skrbeli bodo za nastajanje novih vojaškostrokovnih besedil in udeležence VIU spodbujali h kakovostnemu pisanju o vojaških vsebinah, razvijali vojaško stroko in javno predstavljali vojaški poklic. Pomemben del bi predstavljalo tudi področje učenja iz izkušenj. S statusom inštituta bi omogočali pogoje za samostojno znanstvenoraziskovalno delo pedagoškim delavcem in sodelovanje pri mednarodnih raziskovalnih projektih. Izobraževalni programi bi se pripravili skupaj z zainteresiranimi fakultetami, na katerih bi se izvajali programi za pridobitev izobrazbe in študijski programi za izpopolnjevanje, in sicer za častnike na vseh treh 
bolonjskih stopnjah, za podčastnike pa na srednji, višji in visoki strokovni stopnji (Predlog, 2014).

\subsection{SV skupaj s partnerskimi izobraževalnimi in znanstvenoraziskovalnimi ustanovami $v$ posebnem vojaškem/častniškem modulu akreditira programe vojaškega izobraževanja}

Temelj razvoja novega sistema vojaškega izobraževanja (VIU) Slovenske vojske je vsekakor Doktrina vojaškega izobraževanja in usposabljanja iz leta 2013. Ta daje izhodišča za programiranje, organiziranje, izvedbo, analizo in evalvacijo vojaškega izobraževanja in usposabljanja v Slovenski vojski, kar je podlaga za zagotovitev nujne stopnje znanja, usposobljenosti in moralne integritete slovenskih vojakov ter pogoj za uresničevanje poslanstva in nalog Slovenske vojske. Doktrina VIU temelji na vojaški doktrini in upošteva priporočila ter zahteve na področju vojaškega izobraževanja in usposabljanja zveze Nato in usmeritve, ki izhajajo iz skupne varnostne in obrambne politike EU ter izhodišča in usmeritve, ki izhajajo iz razvojno-usmerjevalnih dokumentov na obrambnem področju. Vojaška doktrina, ki usmerja delovanje vojske, je podlaga za razvoj vojaških ved in znanosti, taktike, tehnik in postopkov za delovanje vojske v različnih okoliščinah, zato je tudi glavno izhodišče za oblikovanje učnih programov vojaškega izobraževanja in usposabljanja. $\mathrm{Na}$ področju vojaškega izobraževanja in usposabljanja se uveljavljajo kakovostna merila, ki veljajo v javnem izobraževalnem sistemu Republike Slovenije. Programi na vojaških šolah so organizirani kot šolski programi, izvajalci izobraževanja pa morajo izpolnjevati predpisane merila in zahteve. Doktrina podpira transformacijski proces Slovenske vojske, uveljavlja nova načela na področju izobraževanja in usposabljanja ter nove in višje kakovostne zahteve za udeležence in izvajalce, spodbuja nove načine razmišljanja o vsebini VIU, ki se mora povezati s sistemom javnega izobraževanja ter doseči primerljive standarde.

Analiza mogočih rešitev razvoja vojaškega izobraževanja je pred leti pokazala, da je za razvoj vojaške stroke in vojaških ved najprimernejša ustanovitev samostojnega javnega visokošolskega zavoda $v$ večjem povezovanju vojaškega izobraževanja $s$ civilnimi izobraževalnimi ustanovami in vzpostavljanju pogojev za akreditiranje programov vojaškega šolanja skladno z merili, ki veljajo za višješolski študij ter I. in II. stopnjo bolonjskega študija. Z integracijo vojaškega in civilnega izobraževanja $\mathrm{v}$ skupnih programih (akreditiranih pri civilnih, javnih višjih in visokošolskih izobraževalnih zavodih) bi kandidati za podčastnike in častnike po končanem izobraževanju imeli javno priznano znanje, ki ga bodo lahko uporabili tako v vojaških kot tudi civilnih poklicih tehnično in menedžersko - upravljavskega značaja. Trenutno ima Slovenska vojska kakovostno izobraževanje, vendar pa se pridobljeni znanje in spretnosti upoštevajo izključno za napredovanja in delo v SV, zunaj SV pa nimajo nobene veljave. Zato bi bili najbolj smiselni preoblikovanje CVŠ v izobraževalni zavod znotraj SV, akreditacija vojaških programov v terciarnem izobraževanju in izvajanje specializacije $\mathrm{v}$ poveljstvih in enotah SV skladno $\mathrm{z}$ enotnimi merili ter nadzorom CVŠ. CVŠ bi tako v sodelovanju z zainteresiranimi srednjimi in višjimi šolami ter fakultetami dijakom in študentom omogočal znanje, 
ki ga potrebujejo častniki in podčastniki Slovenske vojske, razvoj znanja na vojaškem, obrambnem in varnostnem področju, hkrati pa bi zagotavljal andragoški prenos znanja s področja vojaškega voditeljstva, vojaške logistike, vojaškega prava, vojaške sociologije, vojaške psihologije ter drugih družboslovnih področij. CVŠ bi opravljal izobraževalno in znanstvenoraziskovalno dejavnost, ki temelji na teh študijskih področjih. MO in SV bi tako za vsako študijsko leto razpisala določeno število štipendij za izobraževanje oziroma študij na izbranih fakultetah. Skupni programi CVŠ in fakultet bi se izvajali za pripadnike SV, MO, državnih ustanov in tujce v slovenskem jeziku, predmeti bi potekali tudi v angleščini, kar bi omogočalo večjo primerljivost z vojaškimi izobraževalnimi ustanovami v zavezništvu (Predlog, 2014).

Osnovno izobrazbo in s tem poklic častnika na začetni stopnji (poročnik) je mogoče povezati z akreditiranimi programi 1 . bolonjske stopnje ter $\mathrm{z}$ internim programom ŠČ, ki se akreditira na partnerski izobraževalni ustanovi kot vojaški častniški modul. Prav tako se za višjega častnika (major, podpolkovnik) povežejo akreditirani programi na 2 . bolonjski stopnji z internim programom višjega štabnega šolanja PŠŠ, kjer se oblikuje višji vojaški, častniški modul. Tako se poveča kakovost in skrajša čas dosedanjega internega izobraževanja. Nosilci in izvajalci izbirnih predmetov so habilitirani učitelji in visokošolski sodelavci, zaposleni ali zunanji sodelavci Inštituta vojaških ved Slovenske vojske. Za učitelje in visokošolske sodelavce, ki že imajo veljavno habilitacijo, ponovna habilitacija ni nujna. Postopek habilitacije izvede matična fakulteta. Stroške njihovega dela krije Slovenska vojska. Izbirni predmeti - vojaški modul se izvajajo v prostorih, na vadiščih in streliščih ter z opremo Slovenske vojske, ki krije materialne stroške v obliki zagotovitve nujne osebne opreme za študente ter za izvedbo posameznih predmetov in delovne prakse.

Ob tem se kot interne oblike vojaškega izobraževanja in usposabljanja ohranijo tiste, ki imajo funkcijo strokovnega izpopolnjevanja.

\subsection{SV zagotovi z akreditiranimi programi partnerskih izobraževalnih in znanstvenoraziskovalnih ustanov visoko kvalificiran častniški kader različnih smeri}

Uspešno končani izbirni predmeti modula in diploma bi bili tako pogoj za zaposlitev za poklicno opravljane častniškega poklica v Slovenski vojski ali njeni prostovoljni rezervi. Kot izbirne predmete bi jih lahko izbrali vsi študenti fakultet in visokošolskih zavodov partnerske ustanove, univerze. Tako bi se izjemno povečali prepoznavnost in interes za vojaški poklic v civilnih izobraževalnih ustanovah ter možnost, da vojska dobi diplomante poklicnih smeri, ki jih potrebuje za svoj razvoj. 


\section{NEVARNOSTI ZA RAZVOJ SISTEMA VOJAŠKEGA IZOBRAŽEVANJA V SLOVENSKI VOJSKI}

\subsection{Sprejem političnega soglasja v Republiki Sloveniji, da je SV nosilec razvoja vojaških ved in vojaškega poklica}

Srednjeročni obrambni program Republike Slovenije 2016-2020 daje v poglavju o vojaškem izobraževanju podlago za povezovanje z javnim izobraževalnim sistemom oziroma vzpostavitev bolonjskega izobraževalnega sistema v Slovenski vojski (SOPR, 2015). Podobno je zapisano v viziji načelnika Generalštaba Slovenske vojske za leti 2017 in 2018 (Vizija, 2016): »Vojaški izobraževalni sistem oblikovati tako, da bo približal izobraževanje vojaških profesionalcev standardom, veljavnim v civilnem izobraževalnem sistemu, ter vojaškim izobraževalnim sistemom zavezniških držav«. Pot k temu cilju na politični ravni je tudi ustanovitev medresorske delovne skupine med Ministrstvom za obrambo in Ministrstvom za izobraževanje, znanost in šport, katere namen je proučiti možnosti povezave internega vojaškega z javno akreditiranim izobraževalnim sistemom. To pomeni, da politično soglasje po tem vprašanju obstaja.

\subsection{Neuspeli dosedanji poskus ustanovitve vojaške izobraževalne ustanove, ki bi delovala skladno z bolonjskim sistemom (leta 2007)}

Z Ustanovnim elaboratom za formiranje izobraževalne institucije v Slovenski vojski so bile opredeljene možnosti za ustanovitev visokošolske in višješolske ustanove, saj je imel sistem izobraževanja in usposabljanja v Slovenski vojski večinoma značaj funkcionalnega izobraževanja in usposabljanja z interno veljavnostjo in ni imel veljave $\mathrm{v}$ javnem sistemu. Ministrstvo za obrambo si je ob upoštevanju uvajanja bolonjskega sistema izobraževanja $\mathrm{v}$ visoko šolstvo ter $\mathrm{z}$ ustanovitvijo vojaške fakultete želelo zagotoviti optimalen razvoj izobraževalne in znanstvenoraziskovalne dejavnosti na področju vojaških ved in vključiti področje vojaškega izobraževanja v sistem javnega šolstva. Z ustanovitvijo javno priznane ustanove za izobraževanje častnikov in podčastnikov bi imeli pripadniki SV po končanem izobraževanju diplomo in javno priznano znanje, ki bi ga lahko uporabili tudi v civilnih poklicih. Elaborat zaradi političnih sprememb leta 2008 ni bil sprejet (Elaborat, 2007).

\subsection{Neuspeli poskus preoblikovanja Centra vojaških šol iz poveljstva SV v izobraževalno ustanovo, ki bi se s "skupnimi programi« povezovala v bolonjski sistem (2014)}

GŠSV je, ob zavrnitvi Predloga CVŠ: »s ciljem razvoja sistema VIU ocenil, da je treba na strateški ravni najprej izdelati vizijo razvoja sistema VIU (v nadaljevanju besedila: vizija), ki bo definirala poslanstvo in vizijo ter strateške izzive in usmeritve za razvoj sistema VIU. Vizija bo pogled naprej in bo podlaga za izdelavo nove doktrine VIU, izvedbenih predpisov za pravno formalno ureditev VIU in drugi aktov za urejanje področja VIU, za predloge sprememb predpisov (v smislu iskanja optimalnih zakonskih podlag za implementacijo strateških izzivov), oblikovanje srednjeročnih ciljev razvoja sistema VIU v Srednjeročnem obrambnem programu 
2015-2020 in konkretizacijo v poslovnih planih«. V zvezi s tem je bila 2014 ustanovljena delovna skupina za razvoj vojaškega izobraževanja, ki pa svojega dela ni niti dobro začela (Predlog, Zavrnitev predloga, 2014).

Sklep Naš cilj mora biti, da z osnovnim vojaškostrokovnim izobraževanjem izobrazimo in usposobimo podčastnike in častnike za opravljanje temeljnih nalog podčastnika in častnika. Poteka naj kot javni izobraževalni program in daje podčastniku ter častniku javno priznano izobrazbo. Nadaljevalno vojaškostrokovno izobraževanje podčastnikov in častnikov ter usposabljanje vojakov naj bo namenjeno strokovnemu izpopolnjevanju vojaških oseb za opravljanje višjih in zahtevnejših dolžnosti ter pridobitvi višje vojaškostrokovne izobrazbe in usposobljenosti, ki omogoča vojaškostrokovni razvoj in napredovanje v činu. Poklicni sistem v SV pa je v končni obliki zastavljen tako, da temelji na sistemu vojaškega izobraževanja, kar pomeni, da je uspešno končano vojaško izobraževanje doma ali v tujini temeljni pogoj za opravljanje dolžnosti na vseh ravneh v SV. Prišel je čas, da vojaško profesijo izpopolnimo tako, da organiziramo in akreditiramo vojaško izobraževalno ustanovo. Ne samo zato, ker smo se za to obvezali v zavezništvu; v Natu namreč že poteka pospešen proces organiziranja, preverjanja, akreditiranja visokošolskih vojaških ustanov, skladno z bolonjskim sistemom, in večina Natovih držav je ta postopek že opravila. Preurediti jo je treba predvsem zaradi nas in naše vojaške znanosti, saj imamo dobre temelje $\mathrm{v}$ dolgi vojaški tradiciji ter v vojaških intelektualcih, kot so bili Jurij Vega, Rudolf Maister, Vladimir Vauhnik in drugi. Izobraževalna ustanova bi omogočila resen razvoj in napredek slovenske vojaške stroke ter posledično Slovenske vojske. V povezavi z zavezništvi pa bi omogočila, da bi poslanstvo, ki ga opravljamo, temeljilo na našem zanju, ki bi ga na enakopravnih temeljih delili z drugimi ustanovami, vojaškimi in civilnimi, tako doma kot v tujini.

\section{Literatura}

1. Pisanski, Tomaž, ur. (2006): Baron Jurij Vega in njegov čas, Ljubljana:DMFAzaložništvo in Arhiv Republike Slovenije.

2. Brožič, Liliana (2009): Izobraževanje v oboroženih silah. V Rajkovič Vladislav, ur.: Nove tehnologije, novi izzivi: zbornik 28. mednarodne konference o razvoju organizacijskih znanosti. Kranj: Moderna organizacija, 223-229.

3. Brožič, Liliana (2014): 15 let izhajanja Sodobnih vojaških izzivov. www.slovenskavojska. si/vojaski.izzivi.

4. Doktrina vojaškega izobraževanja in usposabljanja, 2013. Ljubljana: Ministrstvo za obrambo Republike Slovenije.

5. Kadetnica, 2011. Ljubljana: Defensor.

6. Kladnik, Tomaž (2007): Slovenska vojska v službi domovine. Ljubljana: Defensor.

7. Kotnik, Igor (2008): Raznolikost izobraževanja vojaških častnikov. V: Rajkovič Vladislav, ur: Znanje za trajnostni razvoj: zbornik 27. mednarodne konference o razvoju organizacijskih znanosti. Kranj: Moderna organizacija, 1126-1140.

8. NATO Education and Training Directive (E\&TD) Bi-SC 75-2, 2013. Norfolk:

9. Predlog razvoja CVŠ v obdobju 2014-2016 (2018), 2015. Maribor: Center vojaških šol.

10. Pešec, Mojca, Krek, Uroš (2015): Can the process of professional military education create military strategists. Sodobni vojaški izzivi, 17-4, 47-61.

11. Standardni operativni postopki za delovanje CVŠ, 2015. Maribor: Center vojaških šol. 
12. Srednjeročni obrambni program Republike Slovenije 2016-2020, 2016. Ljubljana: Ministrstvo za obrambo Republike Slovenije.

13. Toš, Dušan, 2011. Slovensko vojaško šolstvo, zamujena priložnost in izzivi v prihodnosti, Sodobni vojaški izzivi, 13-2, 99-121.

14. Ustanovni elaborat za formiranje izobraževalne institucije v Slovenski vojski (2007), Ljubljana: Poveljstvo za doktrino, razvoj, izobraževanje in usposabljanje.

15. Vaupotič, Karmen, Pavlič, Urška, Rugelj, Tomislav, Hrženjal, Majda, Janusch, Eva, Gaube, Heidi (2012): Ugotavljanje potreb po izobraževanju skladno s potrebami trga dela. Maribor: Fundacija za izboljšanje zaposlitvenih možnosti PRIZMA.

16. Vegič, Vinko, Zabukovec, Stojan (2014): Izobraževanje častnikov: od razpravo organiziranosti k razmisleku o vsebinah. Sodobni vojaški izzivi, 16-2, 57-73.

17. Vizija načelnika Generalštaba Slovenske vojske za leti 2017 in 2018 (2016). Ljubljana: Generalštab Slovenske vojske.

18. Zavrnitev Predloga razvoja CVŠ v obdobju 2014-2016 (2018), 2015. Ljubljana: Generalštab Slovenske vojske.

19. Žabkar, Anton in Svete, Uroš (2007): Šolanje vojaških profesionalcev med tradicionalnimi izhodišči in (post)modernimi izzivi. Bilten Slovenske vojske, 10-1, 183.

20. Žabkar, Anton (2003). Marsova dediščina. Ljubljana: Fakulteta za družbene vede. 


\section{ANALIZA SWOT}

Povezovanje vojaškega izobraževalnega in znanstvenoraziskovalnega sistema $\mathrm{v}$ Slovenski vojski s sistemom izobraževanja in znanstvenoraziskovalnega dela $\mathrm{v}$ Republiki Sloveniji in mednarodnem okolju.

\section{SLOVENSKA VOJSKA}

\begin{tabular}{|c|c|}
\hline PREDNOSTI (znotraj, pozitivne): & SLABOSTI (znotraj, negativne): \\
\hline $\begin{array}{l}\text { - ima oblikovan interni sistem vojaškega } \\
\text { izobraževanja in usposabljanja, ki v temeljih } \\
\text { deluje nespremenjen od leta 1992; } \\
\text { - ima več kot } 20 \text { doktorjev znanosti in več drugih } \\
\text { strokovnjakov, ki bi jih ob ustreznem kadrovskem } \\
\text { izboru ter poklicni poti usmerili v razvoj vojaških } \\
\text { ved; } \\
\text { - ima odlično opremo in infrastrukturo za izvedbo } \\
\text { izobraževalnega ter znanstvenoraziskovalnega } \\
\text { dela; } \\
\text { - ima knjižnično-informacijski in založniški center; } \\
\text { - ima svojo znanstveno-strokovno publikacijo; } \\
\text { - v omejenem obsegu razpolaga z ustreznimi } \\
\text { financami; } \\
\text { - ima dostop in možnost povezovanja ter izmenjave } \\
\text { učiteljev in študentov ter vključevanje v ZR- } \\
\text { projekte v Natu in EU. }\end{array}$ & $\begin{array}{l}\text { - ni nosilec razvoja vojaških ved in posledično } \\
\text { vojaškega poklica; } \\
\text { - nima oblikovane osrednje pedagoške in } \\
\text { znanstvenoraziskovalne ustanove; } \\
\text { - nima oblikovanega izobraževalnega in } \\
\text { znanstvenoraziskovalnega sistema ter } \\
\text { izoblikovanih in razvitih znanstvenih disciplin } \\
\text { vojaških ved z ustreznimi nosilci, ki bi se } \\
\text { vključevali v (civilno) javno in mednarodno } \\
\text { vojaško pedagoško in znanstvenoraziskovalno } \\
\text { okolje; } \\
\text { - nima javno akreditiranih programov } \\
\text { izobraževanja. }\end{array}$ \\
\hline PRILOŽNOSTI (zunaj, pozitivne): & NEVARNOSTI (zunaj, negativne): \\
\hline $\begin{array}{l}\text { - SV skupaj s partnerskimi izobraževalnimi in } \\
\text { znanstvenoraziskovalnimi ustanovami: } \\
\text { - postane nosilec razvoja vojaških ved in posledično } \\
\text { vojaškega poklica; } \\
\text { - s svojimi kadri vzpostavi osrednjo pedagoško in } \\
\text { znanstvenoraziskovalno ustanovo v obliki inštituta } \\
\text { vojaških ved; } \\
\text { - oblikuje izobraževalni in znanstvenoraziskovalni } \\
\text { sistem ter izoblikuje in razvija znanstvene } \\
\text { discipline vojaških ved z ustreznimi nosilci, ki so } \\
\text { vključeni v (civilno) javno in mednarodno vojaško } \\
\text { pedagoško in znanstvenoraziskovalno okolje; } \\
\text { - zagotovi visoko kvalificiran častniški kader } \\
\text { različnih smeri; } \\
\text { • v posebnem častniškem modulu akreditira } \\
\text { programe vojaškega izobraževanja. }\end{array}$ & $\begin{array}{l}\text { - politično soglasje, da je SV nosilec razvoja } \\
\text { vojaških ved in posledično vojaškega poklica; } \\
\text { - neuspeli dosedanji poskus ustanovitve svoje } \\
\text { vojaškoizobraževalne ustanove, ki bi delovala } \\
\text { skladno z bolonjskim sistemom (leta 2007); } \\
\text { - neuspeli poskus preoblikovanja Centra vojaških } \\
\text { šol iz poveljstva SV v izobraževalno ustanovo, ki bi } \\
\text { se s »skupnimi programi« povezovala v bolonjski } \\
\text { sistem (2014). }\end{array}$ \\
\hline
\end{tabular}

Avtor: Tomaž Kladnik 